5) 脇丸俊博 - 杉岡洋一: 実験的変形性関節症の微 細構造変化 (第二報). 整外と災外. 24 巻 1 号, 69-71, 1975.

6) Ehrlich, M. G., Mankin, H. J., Jones, H.,
Grossman, A., Cripsen, C. and Ancon, D.: Biochemical Confirmation of an Experimental Osteoarthritis Model. J. B. J.S. 57-A, 392-396, 1975.

\title{
電気角度計を利用しての臨床的歩行分析
}

\author{
熊本理学診療科病院 \\ 武田幸之助・堀尾慎弥 \\ 徳 永温正・河野正通
}

\section{Clinical Evaluation of Gait Patterns with Electrogoniometer}

\author{
By
}

\author{
K. Taketa, S. Horio, A. Tokunaga \& M. Kôno \\ Kumamoto Rehabilitation Hospital
}

\begin{abstract}
Gait pattern could be evaluated with a simple method consisted of the popular clinical equipments, such as clinical E. M. G. kit, electrogoniometer and telemeter system.

Obvious differences between healthy men and hemiplegia patients were observed.

These results strongly suggested that the method might be convenient and clinically useful.

This paper was described about the method and the results.
\end{abstract}

\section{はじめに}

整形外科やハビリーションに携る者にとっては，研 究のためばかりでなく, 日々の診療のためにも歩行分 析装置が必要であり，心電図や脳波のように簡便にデ ーターを入手する必要がある.

しかし，人間の歩行は多元的要素を含み，その解析 も多面的になされる必要があるため, 歩行分析装置は 複雑なものになりがちであり, 多額の経費を必要とす るものが多くなる。

われわれは，一般的に利用されている臨床用筋電計 とテレメーターを使用し, 自作せる膝用電気角度計と 小型マイクロフォンにて歩行分析装置を構成し, 日々 の診療に利用しているので, その方法を紹介し, 諸賢 の御批判を得たいと思う.

\section{装}

置

1. 筋電計; 日本光電社製レコーダ付筋電計, Mod- e1 MM-22A，チャンネル数は 2 個, 医用テレメータ 一受信機よりの入力, および電気角度計よりの入力が 可能, ただし, タイムコレスタレトにDCを附加して いる.

2. 医用テレメーター; Narco 社製 FM-1100 E2 送信機および FM-1100-6 受信機, 送信機は $18 \mathrm{gr}$ と軽量.

3. 電気角度計 ; 外側支柱のみの膝装具様構造をし ており, 接手部分に直線変化型可変抵抗器を装着し, 約 $15 \mathrm{~m}$ の可橈ケーブルを介してブリッヂボックスに つながる。重量は $650 \mathrm{gr}$, 過伸展 $15^{\circ} よ り$, 屈曲角 $120^{\circ}$ まで測定可能, 左用右用は別々.

4. 小型マイクロフォン; 小型マイクロフォンを靴 に密着し, 鞉の接床振動をテレメーターにより送信, 接床時わよび離床時振動の弁別により, 立脚期, 遊脚 期，両側支持期を左右同時に記録可能.

上記の装置にて, (1)目的とする筋肉の筋電位変化, (2)滕関節の角度変化, (3)靴の接床振動, を任意に $2 つ$ 


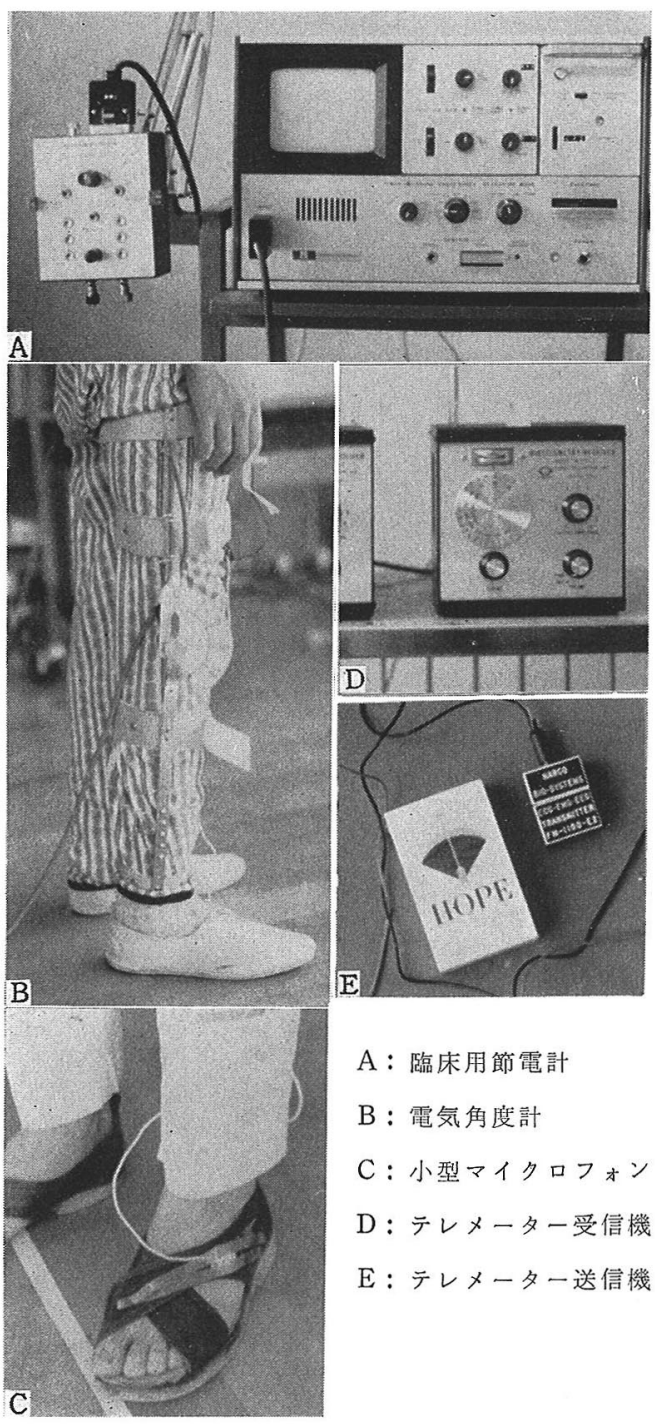

図 1

組合わせ，被検者が約 $30 \mathrm{~m}$ の範囲で自由に歩行する 一歩一歩の歩行を 連続的に 記録する。記録紙の現像 は,レントゲン写真用自動現像装置にて即時的に可能 でありデーターの入手判続が，あたかる心電図のと きと同様の感じである.

症例

図 2（A）は，当病院に勤務している健康人の滕関 節角度变化曲線である，破線は刻時表示であり，寒線 は第1 チャンネルの輝線であるが，との破線と実線の

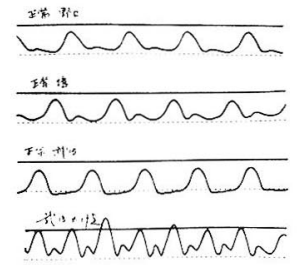

A

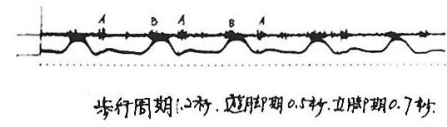

$\mathrm{C}$

図 2
間の電位差が $90^{\circ}$ になるように調整されていて，破線 上が $0^{\circ}$, つまり㯟伸展位, 寒線上が膝 $90^{\circ}$ 属曲位で ある。刻時は $1 / 10 \mathrm{sec}$ ，掃引速度は $10 \mathrm{~cm} / \mathrm{sec}$ とし ている.

健康人の場合, 膌関節角度変化は放物線型に屈曲伸 展して遊脚期を形成する。滕が最大伸展して立脚する と同時にすぐに属曲し，再び最大伸展して立脚期が終 るが，遊脚期に移行する直前で小属曲する，普通に歩 いた場合，歩行周期は 1.1 1.3 秒である．立脚期は 歩行周期の $60 \%$ を占》，避脚期が $40 \%$ を占めるとい われているが，われわれの方法でも同様の成績が得ら れているととが明膫である，立脚直後に起とる㯟の小 屈曲（約 15）は体重の移動をスムースに行なうため に起とるものであらうが, 歩行の特徽をとらえるため にも，また滕関節の機能を考光る上にも重要なポイン トであろうと思っている，歩行速度が速くなり，走る 状態になるにしたがい立脚期は短かくなり，膝関節角 度変化が大きくなり，立脚初期の膝属曲も著明とな る。

図 2（B）は，正常人の滕関節角度曲線之，表面電 極による筋電図を同時に記録したものであるが，歩行 周期々各嗍の活動の相関は, 他の研究者の報告と一至 しており，しかも它の判読は一目嘹然としていると自 真している.

図2（C）は，正常人の滕関節角度変化曲線と足部 接休振動（足音）との同時記録である。足部接床振動 は, 接床時振動 $\mathrm{A}$ と離床時振動 $\mathrm{B}$ とを区別出来, 接床 時には滕は最大伸展をなし，離床時には滕はすでと少 し属曲していることが判る。

症例 1。図3（A）は陳旧性片磨痺患者の膝関節角 
度変化曲線であるが, 遊脚期の変化が健康者の放物線 型変化と異り, 台型を示し, 最大屈曲の值も減少して いて共同運動のために滕のスムースな運動が阻害され ていることがよく反映されていると思う。また立脚期 が短かくなり，立脚初期屈曲が消失している。

症例 2. 図3（B）は他の陳旧性片麻舫患者のもの で, 膝関節角度変化曲線と表面電極による筋電位変化 を組合わせたデーターであるが, 膝関節の最大屈曲角 が $30^{\circ}$ 以下で斿脚波型が台型であり，伸展共同運動が 強く, 棒足様歩行をしている患者の状態がよく反映さ れていると考えている。 そして筋電図により，外側八 ムストリングスはよく分噰しているが，大腿直筋，前 脛骨筋，下腿三䫏筋は，遊脚期，立脚期共に間断なく 放電し, 筋の分㒕運動が出来ていないのが裏付けられ ている.

症例 3. 図3（C）はごく軽度の内反尖足を残すの みにて, 各関節の分雁運動も良好で, 無杖歩行可能で あり, 装具も必要としない患者の㯟関節角度変化曲線 の左右を比較したものであるが，患側に於いて立脚初 期にスムースさを欠き，軽度に残存している内反尖足 が歩行阻害因子として働いていることが推測される.

症例 4 . 図 3（D）は，歩行訓練をはじめたばかり の片麻瘏患者の膝関節角度変化と, 前陘骨筋の活動に ついて左右差を比較したものであるが，歩行周期が 3 秒で正常人の 2 倍以上かかっており，患側立脚がきわ めて不安定であるためか，健側の遊脚期も非常に短か い. 前脛骨筋のとる態度も, 健側と患側とでは異り, 健側の場合その最大活動は遊脚期に一致しているが, 患側では立脚初期に一致している.

症例 5 .図 4 （E）は小脳変性により失調性歩行を 呈する患者であるが，歩行周期が一定せず，膝関節の 最大屈曲値も一定せず，㬵関節の最大屈曲値も一定し ていないでいわゆる千鼠足歩行であることが明瞭であ る.

\section{結語}

われわれは，一般的に利用されている臨床用筋電計 とテレメーターを使用し，さらに自作の㯟用電気角度 計および小型マイクロフォンを組合わせて歩行分析装 置を構成し，日々の診療に利用している．われわれの 方法では歩周期と筋電の相関が一目瞭然としてとらえ るととが出来る.

被検者が約 $30 \mathrm{~m}$ の範囲で自由に歩行する一歩, 一

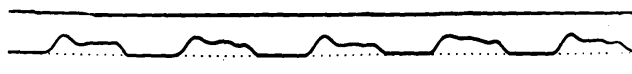

A

fo. 3 .5专野这第

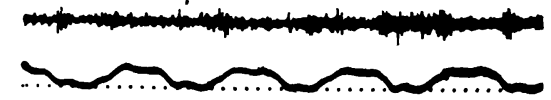

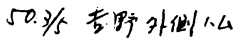
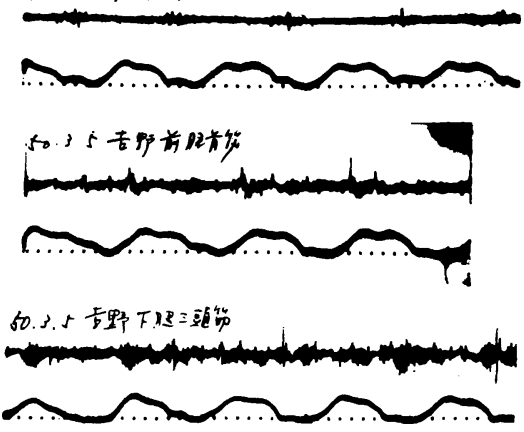

B

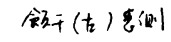
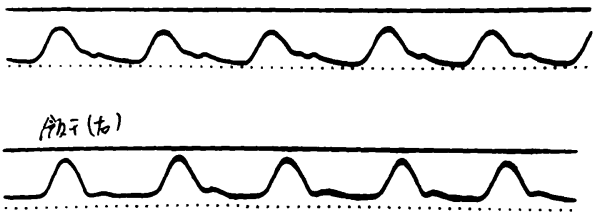

C

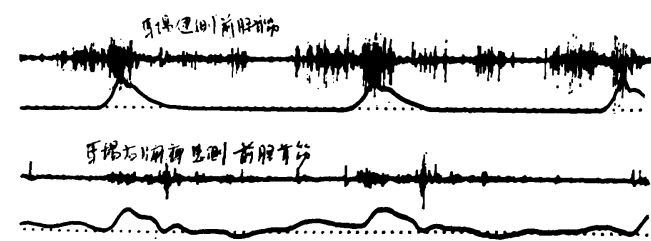

D

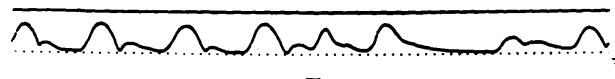

E

図 3

歩の歩行を連続的に曲線として記録出来るため, 種々 の病態を特徴ある所見としてとらえるてとが出来る. またデーターの入手判読もきわめて容易であり, あた かも心電図のときと同様の感じであるが，まだまだ不 十分である.今後も改良を続けながら，データーを集 積して手術適応の決定や術後成績の判定, 装具の効果 
判定などにも 役立つものとしていきたいと考えてい る.

\section{文献}

1）中村 隆：リハビリテーションに招ける筋電 図. 医歯薬出版, 1973.

2）天児民和・他：運動療法。医菌薬出版，1972.

3）乗松敏晴 - 他：整形外科. 4, 297，1973.

4）熊谷隆彦：日整会誌，46,416, 1972.
5）松村 秩：理学療法と作業療法. 2, 3， 128, 1975.

6）松村 秩：理学療法と作業療法. 4, 223, 1975.

間長崎大学 鈴木 良平 本研究は膝関節のみに対して行なわれているようで すが，股関節，足関節についてはまだ研究しておられ ませんか。

\title{
原 始 反 射と運 動 発 達 \\ 一正常児について—
}

長崎大学整形外科
䅖 山 富太郎・伊 藤 信 之
鈴 木 良 平

長崎県立整肢療育園

川口幸 義

\section{Primitive reflexes and motor development}

\author{
By
}

\author{
T. Akiyama, N. Itoh, R. Suzuki \\ \& Y. Kawaguchi \\ Department of Orthopaedic Surgery, Nagasaki \\ University School of Medicine
}

\begin{abstract}
We studied on the relation between primitive reflexes and motor development by means of taking movie.

Primitive reflexes (Moro reflex, Asymmetrical tonic neck reflex, Crossed extension reflex. Babinshi reflex ete) activate all kinds of automatic movement integrated by higher brainstem, and furthermore these reflexes activate development of righting reaction, parachute reaction, balance reaction and voluntarity.

Namely, primitive reflexes activate mainly automatic movement but these reflexes exert too promotive influence on the development in the early stage learning anti-gravitic posture and normal sensori-motor pattern in each motordevelopmental stage.
\end{abstract}

原始反射が運動発達に及ぼす影響について，正常児 10 例, 脳性麻瘦児 10 例の経時的な映画記録観察から 考察を加えたので以下報告する．新生児は全身的な屈 筋緊張優位により，屈曲姿勢をとっていて，頭の自動 的な回旋運動と原始反射の支配下にある四肢の自動運 動を除けば，重力のなすがままの状態（従重力姿勢）
にあるが，新生児期を過ぎる頃より，腹卧位における 貴の持ち上げが可能となりはじめ, 徐々に伸展笳緊張 が高まるとともに，腹臥位での抗重力姿勢保持機能が 発達してきて，手指を開いた上肢を頭の前方へ差し出 し，上半身を支えるととが可能となる．同時に，同肢 位での, 分髉的な足関節自動背屈を伴った蹴り運動が 